Relations industrielles

Industrial Relations

\title{
P.B. Beaumont, Change in the Industrial Relations: The Organization and Environment
}

\section{Anthony E. Smith}

Volume 46, numéro 1, 1991

URI : https://id.erudit.org/iderudit/050660ar

DOI : https://doi.org/10.7202/050660ar

Aller au sommaire du numéro

Éditeur(s)

Département des relations industrielles de l'Université Laval

ISSN

0034-379X (imprimé)

1703-8138 (numérique)

Découvrir la revue

Citer ce compte rendu

Smith, A. E. (1991). Compte rendu de [P.B. Beaumont, Change in the Industrial Relations: The Organization and Environment]. Relations industrielles /

Industrial Relations, 46(1), 238-239. https://doi.org/10.7202/050660ar

Tous droits réservés @ C Département des relations industrielles de l'Université Laval, 1991
Ce document est protégé par la loi sur le droit d'auteur. L'utilisation des services d'Érudit (y compris la reproduction) est assujettie à sa politique d'utilisation que vous pouvez consulter en ligne.

https://apropos.erudit.org/fr/usagers/politique-dutilisation/ 
What is wrong with this book? Not much really. I found the theoretical chapter, which reviewed three competing approaches to comparative analysis of business organization (contingency theory, political economy and what Lane calls the cultural/institutional approach) to be not very illuminating. I also felt that Lane's dogged adherence to her three country design was, in the final result, a bit too rigid. There is, for example, almost no discussion of the work humanizing movement in Scandinavia where it reached its highest level of development. Nor is there much discussion of Japanese practice and the impact of Japan on the current flexibility debate. As a result this book might be usefully assigned as part of a course on comparative IR/HRM, but it would have to be generously supplemented with additional materials.

The positive aspects of Management and Labour in Europe are many and its faults are few. I highly recommend it for anyone seriously interested in comparative IR and HRM.

Roy J. ADAMS

McMaster University

Change in Industrial Relations: The Organization and Environment, by P.B. BEAUMONT, London, Routledge, 1990, 347 p., ISBN 0-415-04344-1.

There has long been a tendency to look across the Atlantic and south of the border for solutions to Canadian problems or images of the future. In the broadly defined field of industrial relations this tendency has been particularly marked. Some have seen America's "free" labour market as the way to create jobs. Others have viewed with dismay declining employment in traditional manufacturing industries and reductions in union membership. Developments in the industrial relations system such as concession bargaining and employee involvement programmes have attracted attention. Recently, British managers and academics have begun to use the jargon of "human resource management" in an attempt to keep up with American fashion. So what has been happening in industrial relations? This book, drawing on insights from economics, organizational behaviour, and urban and regional research, as well as from the traditional industrial relations literature, aims to provide some of the answers. Its well-known author claims not only to describe and interpret recent developments but also to raise the question of where industrial relations is going in the future.

Focusing on collective bargaining, the author examines changes in the British system of industrial relations in the $1980 \mathrm{~s}$, and places them in a wider context by frequent reference to developments in the USA. The 1980 s witnessed a wide range of changes in industrial relations in Britain, such as the growth of non-union firms, trade union decline, the emergence of human resource management practices, and an increase in labour-management co-operation. As a result, there is increased controversy about its future development. Although the book is not explicitly based on a comparative or cross-national framework of analysis, the approach adopted has been influenced by Kochan's American-based book, Collective Bargaining and Industrial Relations (1980). The essence of the conceptual approach adopted is that certain independent variables (notably the external environment, the bargaining characteristics of management, the organizational characteristics of unions, and bargaining structure) impact on certain dependent variables associated with collective bargaining. Namely the negotiations process, bargaining outcomes, contract administration and the union-management change process which, in turn, feed through to shape the goal attainment of the parties. The approach adopted here, however, differs from that of Kochan in treating industrial relations somewhat less of a discrete, self-contained entity, both in the individual-organization and wider-society settings. 
For example, the author emphasizes that some of the most important effects on industrial relations arise from decisions in an organizational context that are not solely taken by industrial relations professionals, nor taken for exclusively industrial relations reasons.

The author is careful to avoid a simple prescriptive approach, emphasizing, in particular, that employers in Britain who are seeking more integrative collective bargaining but who do not achieve it, do not only have the option of removing bargaining arrangements and substituting human resource management practices. They can also seek to increasingly circumvent collective bargaining by taking more decisions at non-collective bargaining levels. Here he draws attention to the varying success of this development on a systematic basis in the USA from the early 1970s. In Britain, systematic moves in this direction, involving a coherent, longterm management strategy, are more difficult to discern, although undoubtedly a number of more piecemeal, ad hoc moves along these lines have occurred. But the underlying message is clear: it is only if and when the nature of management strategy (the outcome of which will be strongly shaped by the ongoing interaction between product markets and management value systems) becomes clearer, will it be seen whether the British system of industrial relations remains one largely centred around collective bargaining.

With its clear message, its wide range of information, and its authoritative sources, the book has considerable merits and is likely to be used widely as reference book whose varied contents can be "selectively dipped into" by students from a variety of British industrial relations courses. But its larger ambitions are not achieved. Empirically, some complex tendencies are reduced to clear-cut trends in one direction. Analytically, the conceptual approach seems vacuous. The author states that "some of the most important influences on industrial relations are to a considerable degree exogenous to the control of the leading actors in the industrial relations sub-system, as conventionally defined - a fact that has important implications for the research, teaching and practice of industrial relations". Who would disagree? This kind of statement, over-general and yet not comprehensive, is typical of the literature on the systems approach to the study of industrial relations. And yet the framework is so broad that it does not directly inform the analysis: it is constantly mentioned, but what does it explain? It is not comprehensive because it reduces the conflicts and contradictions of relations between employers and workers to bland outputs that are determined by the interaction between the environment and collective bargaining. The idea that the strategy is there to control workers hardly enters, and the history of industrial relations is rendered anaemic. It is therefore perhaps no surprise that the weakest chapter of the book is that on trade unions, for it analyzes union membership and some attitude surveys but does not begin to identify what all the changes have really meant for life at the workplace.

The picture is also limited in more obvious ways. Non-union competition is equated with sophisticated personnel management. Aggressive union-busting campaigns enter in a sanitized form. And the book discloses little about the impact of contemporary management policies of consultation, participation, and organizational development on workers with low wages, harsh working conditions, and no job security.

The book however does offer a valuable picture of some very important changes; and the issues that it raises concerning the extent and likely future direction of new forms of unionmanagement relations deserve to be widely debated. Not least because the introduction of many of these forms is being considered in Canada. But its analysis is too bland to be satisfying. As Edwards commented when reviewing a book that adopted a similar conceptual approach (The Transformation of American Industrial Relations, Kochan et al. 1986) it is "industrial relations with the politics taken out". 